\title{
ЕНЕРГЕТИЧНА КОНЦЕПЦІЯ ЖИВОГО. НОВИЙ ПІДХІД У БОРОТЬБІ З РАКОМ
}

\section{В. С. Щукін}

Викладено новий підхід до проблеми боротьби із злоякісними пухлинами, що ґрунтується на запропонованій автором енергетичній концепції (ЕК) живої речовини. Одним з положень концепції є розгляд організму людини як складової частини організму вищого - порівняно з самою людиною - рівня організації живої речовини, а саме - Біосфери.

Такий підхід визначається нами як «геобіоцентризм», протиставляючи його антропоцентризму, який лежить в основі сучасного природознавства. 3 позицій геобіоцентризму організм людини є відкритою біологічною системою, що не самоорганізовується, яка знаходиться під повним контролем геофізичних факторів, які не лише визначають морфогенетичні особливості кожного живого організму та напрям їхніх безперервних еволюційних змін, але і регулюють тривалість життя кожного з них, включаючи людину. До таких факторів належать електромагнітне поле Землі і склад атмосферного повітря, а точніше - надлишок в ньому кисню і нестача вуглекислого газу. Поєднання останніх і їхня спільна дія на організм людини є, згідно з концепцією, що пропонується, основою для розвитку, зокрема, пухлинної хвороби. На підставі висновків, які автор підтверджує встановленими наукою фактами, запропоновано новий спосіб профрілактики та усунення з організму людини злоякісних пухлин.

Ключові слова: злоякісна пухлина, жива речовина, кисень атмосфери, біосфера, гіпоксія, гіперкапнія, тривалість життя.

\section{ЭНЕРГЕТИЧЕСКАЯ КОНЦЕПЦИЯ ЖИВОГО. НОВЫЙ ПОДХОД В БОРЬБЕ С РАКОМ}

\begin{abstract}
В. С. Щукин
Изложен новый подход к проблеме борьбы со злокачественными опухолями, основанный на предлагаемой автором энергетической концепции живого вещества, рассматривающей человеческий организм как открытую несамоорганизующуюся биологическую систему, входящую в состав организма более высокого уровня организации - Биосферу, и находящуюся под полным контролем геофизических фракторов - в первую очередь электромагнитного поля Земли и состава атмосферного воздуха. Указанные факторы решающим образом определяют продолжительность жизни - видовую и индивидуальную - любого живого организма, включая человека. На основании изложенного подхода предложен новый способ профилактики и устранения из человеческого организма злокачественных опухолей.
\end{abstract}

Ключевые слова: злокачественная опухоль, живое вещество, кислород атмосферы, биосфера, гипоксия, гиперкапния, продолжительность жизни.

\section{ENERGY CONCEPT ALIVE. NEW APPROACH IN THE FIGHT AGAINST CANCER}

\section{S. Shchukin}

New approach to the problem of struggle with malignant tumors based on the suggested by the authors energetic concept of living matter considering a human organism as an open non-self-organizing biological system that is the part of organism of a higher level of organization - Biosphere, and that is under full control of geophysical factors - first of all electromagnetic field of the Earth and composition of atmospheric air is set forth. The mentioned factors fatefully determine length of life - specific and individual - of any living organism, including human being. On the basis of the set forth approach a new means of prevention and removal from the human organism of malignant tumors was suggested.

Key words: malignant tumor, living matter, oxygen of the atmosphere, Biosphere, hypoxia, hypercapnia, length of life.

Автор висловлює глибоку вдячність професору В. С. Мосієнко, Інститут експериментальної патології, онкології і радіобіології ім. Р. Є. Кавецького НАН України; професору Г. Л. Апанасенку, Національна медична академія післядипломної освіти імені П. Л. Шупика та професору Г. Н. Бахімеву, Міжнародна академія наук та інноваційних технологій (МАНІT) за допомогу у підготовці цієї статті. 
Вступ. Представимо погляд на одну 3 центральних проблем сучасної медицини - проблему лікування пухлинної хвороби - 3 позицій принципово нового підходу, який ми назвали «Енергетичною концепцією живого» (ЕК).

Мета роботи: привернути увагу науковомедичної спільноти до тих можливостей, які відкриваються перед практичною онкологією у тому випадку, якщо визнати вірною ЕК. Частково основні положення нового підходу викладені в [1] і роботах інших авторів.

Результати та їх обговорення. Найбільшу складність, на нашу думку, становить перехід від вже усталених поглядів до ЕК на рівні аксіом, тобто положень, які повинні прийматися без доказів. Наприклад, аксіомою сучасної біології $\epsilon$ твердження типу: «Організм людини є складною системою, що самоорганізовується», тоді як одна 3 аксіом ЕК виражається наступним чином: «У природі не існує систем, які самоорганізовуються, всі системи, включаючи організм людини, «самоорганізовуються» ззовні потоками зовнішньої енергії, які представлені факторами зовнішнього середовища».

Зазначені аксіоми утворюють своєрідний «вододіл» в сучасному природознавстві, включаючи, звісно, медицину. Якщо визнати правоту аксіоми сучасної біології, то причину всіх людських хвороб слід шукати всередині людського організму, що видається абсолютно логічним. Якщо ж виходити 3 наведеної аксіоми ЕК, то також логічно абсолютно обгрунтованим видається висновок про те, що справжні причини всіх, без будь-якого винятку хвороб організму людини знаходяться поза його фізичними межами, у зовнішньому для нього середовищі, а всередині самого організму ми спостерігаємо лише прояви їхньої дії. У зв'язку з цим виклад основних положень ЕК (тез) видається необхідним для логічного обгрунтування пропонованого, зрештою, способу боротьби із злоякісними пухлинами.

\section{1. Тези загального порядку}

Теза 1. У природі відсутні системи, що самоорганізовуються, якщо під цим терміном розуміти системи, у яких характер змін внутрішніх структур не визначається характером змін потоків зовнішньої енергії. У будь-якій природній системі потоки цієї енергії при взаємодії з внутрішніми структурами відповідної системи запускають всі процеси «самоорганізації» (еволюції) зазначеної системи. Отже, характер змін внутрішніх структур природ- них систем повністю визначається характером змін потоків зовнішньої енергії, що взаємодіють з внутрішніми структурами зазначених систем. У цьому сенсі системою, що організується сама, може бути визнана лише та система, зміни в якій не пов'язані 3 характером змін потоків зовнішньої енергії.

Так, [2]: «Г. Фьорстер (1964) стверджує: «Таких речей, як системи, що самоорганізовуються, не існує!.. Цей термін втрачає сенс, якщо система не перебуває в тісному контакті з оточенням, яке володіє доступними для неї енергією і порядком і 3 яким наша система перебуває у стані постійної взаємодії». 3 тези 1 логічно обгрунтовано випливає теза 2.

Теза 2. Організм людини, як і будь-яке інше матеріальне утворення світу живої та неживої природи, не $\epsilon$ системою, що самоорганізовується, а вся його «самоорганізація» як в онтогенезі, так і філогенезі, а також в загальній еволюції живої речовини, здійснюється ззовні факторами зовнішнього середовища, що оточує його (потоками зовнішньої енергії), що визначають, зокрема, його морфологічні особливості, фізичні розміри, його граничну видову та індивідуальну тривалість життя і напрямок еволюційного розвитку. До вказаних факторів відносяться, в першу чергу, електромагнітне поле Землі і склад атмосферного повітря.

Прийняття тези 2 може значно змінити пріоритети сучасної біології та медицини, які продовжують пошуки причин старіння і розвитку всіх пов'язаних 3 ним захворювань всередині самого організму.

Теза 3. Оскільки зазначені в тезі 2 фактори зовнішнього середовища $є$ визначальними для видової тривалості життя людини, можна стверджувати, що, змінюючи певним чином інтенсивність, спрямованість і тривалість дії зазначених факторів на організм людини можна продовжити людське життя поза його нинішню видову межу шляхом усунення або запобігання виникненню захворювань, що перешкоджають цьому, насамперед тих, які прийнято асоціювати зі старінням, включаючи онкологічні.

Перевірити вірність тези 3 можна в ході медичного експерименту, заклик до проведення якого i $\epsilon$ однією з цілей цієї статті.

Зв'язок розвитку в людині хвороб, що асоціюються зі старінням, 3 дією електричного та гравітаційного полів планети, розглянуті в статті [1]. У цій статті буде теоретично, на основі експериментальних даних, обгрунтована можливість профілактики та усунення пухлинної хвороби шляхом 
зміни складу вдихуваного людиною повітря. Але спочатку необхідно визначитися 3 концепціями антропо- і геобіоцентризму.

\section{2. Геобіоцентризм проти антропоцентризму}

В основі сучасного природознавства лежить, без сумніву, принцип антропоцентризму, суть якого полягає приблизно в наступному. Сучасна наука розглядає Homo sapiens як вершину еволюції Всесвіту, на кожному кроці підкреслюючи не лише їі винятковість, але і ії відособленість від решти Природи. Постійно лунають заяви про те, що людина своєю господарською діяльністю руйнує біосферу, завдає їй істотної шкоди і навіть здатна зробити цю шкоду непоправною. Наприклад, людина вирубує тропічні ліси, забруднює моря і океани і, тим самим, сприяє зміні клімату на планеті в бік його погіршення. Кіотський протокол підкреслює, що глобальне потепління пов'язане з господарською діяльністю людини, що шкодить Природі. Вже в самих твердженнях Протоколу закладена ідея протиставлення людини і Природи, тоді як академік В. І. Вернадський зазначав, що людина з їі розумом є такою ж природною продуктивною силою, як сила вітру, Сонця, води, корисних копалин тощо. Виходячи з цієї позиції великого вченого, сформулюємо основну ідею геобіоцентризму.

Геобіоцентризм є світоглядною системою, відповідно до якої людина є невід'ємною частиною організму вищого - у порівнянні з людиною - рівня організації живої речовини, а саме: Біосфери. Біосфера, у свою чергу, складається 3 маси неживої речовини (вся маса речовини планети), маси живої речовини (сумарна маса всіх живих організмів), а також електромагнітного поля Землі (ЕМПЗ), що є енергетичним каркасом організму Біосфери. ЕМПЗ розподіляє енергію, що надходить ззовні, між неживою і живою речовинами Біосфери [1].

Сама назва - геобіоцентризм (а не, наприклад, біогеоцентризм) - говорить про те, що його основою $є$ положення про домінування неживої речовини над живою. Це означає, що сили неживої природи, головним чином ЕМПЗ, вирішальним чином впливають на чисельність і відтворення організмів різних видів, їх різноманіття, морфологічні особливості та фізичні розміри будь-якого з організмів, видову тривалість життя організмів, включаючи людину, і загальний напрямок еволюційного розвитку Біосфери. Однією з переваг геобіоцентризму $\epsilon$ можливість, виходячи із закономірностей, встановлених для світу неживої природи (наприклад, геології), визначення напрямку подальшої еволюції як Біосфери в цілому, так і людини зокрема. Антропоцентризм же, оголошуючи Homo sapiens «царем природи», повністю втрачає орієнтири у визначенні цих напрямків, подібно альпіністу, що підкорив вершину і має тепер лише один шлях вниз. Тепер звернемося до складу вдихуваного людиною повітря.

\section{3. Про кисень атмосфери}

Згідно з ЕК, поява кисню в атмосфері викликана вичерпанням можливості маси живої речовини, що утворилася на ранніх стадіях існування біосфери, поглинати і зв'язувати (асимілювати) енергію, що безперервно надходить ззовні (що, згідно 3 ЕК, є його головною біологічною функцією). Ту частину енергії, поглинання якої загрожувало масі живої речовини розривом молекулярних зв'язків і загибеллю, жива речовина зв'язувала в молекулу кисню і «викидала» його в атмосферу. Звідси важлива теза 4.

Теза 4. Кисень атмосфери - це упредметнена зовнішня енергія, яка не зазнала остаточної асиміляції масою живої речовини фотосинтезуючих рослин і - в буквальному сенсі слова - «повисла у повітрі» в «очікуванні» можливостей для своєї остаточної асиміляції.

Така можливість на планеті Земля з'явилася 3 появою живих істот, для існування яких кисень $є$ життєво необхідним (згідно з ЕК, зазначені істоти були створені природою саме 3 цією метою - поглинати і зв'язувати вільну енергію Біосфери у вигляді кисню). У ході їхнього дихання кисень віддає свою енергію, а живі організми використовують пї на підтримку своєї життєдіяльності.

Розглянемо склад вдихуваного і видихуваного людиною повітря [3]:

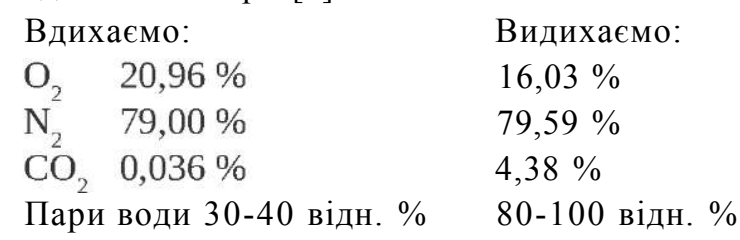

Уважне вивчення наведених цифр дозволяє зробити такі висновки:

1) людині для дихання не потрібні $21 \%$ кисню, наявні в атмосфері, іiі організм споживає не більше $(20,96-16,03)=4,93 \%$, решту він повертає в атмосферу;

2) очевидно, що за градієнтом концентрації $(0,04 \%$ проти 4,38\%) атмосфера «витягує» 3 людини $\mathrm{CO}_{2}$. Можна припустити, що якби вміст $\mathrm{CO}_{2}$ в атмосфері був більшим, то кількість його, 
що утримується організмом людини, також би збільшилася.

Поставимо собі запитання - а який склад вдихуваного повітря був би оптимальним для організму людини з точки зору можливості продовження ii життя?

Те, що нинішній склад атмосфери не є оптимальним, зокрема, за киснем, відомо давно. Так, в [4] говориться: «... Як показують фізіологічні експерименти, у багатьох видів оптимальний ріст відбувається при вмісті в середовищі $10 \%$ кисню, що вдвічі нижче його вмісту у сучасній атмосфері. У міру того, як вміст кисню починає перевищувати цей оптимальний рівень, і фотосинтез, і дихання все більше пригнічуються».

Звернемо увагу на наступний факт - надлишок кисню пригнічує дві найважливіші і прямо протилежні фізіологічні функції - дихання, в ході якого кисень утилізується, і фотосинтез, в ході якого кисень утворюється. Цей факт дає підстави зробити нижченаведене припущення у вигляді тези 5 .

Tеза 5. Виходячи з єдності походження та біохімічного складу всього живого [5] і того факту, що надлишок кисню атмосфери пригнічує як функцію фотосинтезу, так і функцію дихання, можна припустити, що нестача вуглекислого газу в атмосфері повинна справляти вплив, аналогічний надлишку кисню, а саме: одночасно пригнічувати як фотосинтез, так і дихання.

Для 3'ясування того, яка кількість $\mathrm{CO}_{2}$ в атмосфері є оптимальною для фотосинтезу, звернемося до [6]: «Ми можемо відрізняти чотири рівні в концентрації $\mathrm{CO}_{2}$ : перший рівень, від 0,0 до 1,5\%, коли енергія фотосинтезу може зростати прямо пропорційно збільшенню концентрації, причому величина цієї концентрації, при якій енергія фотосинтезу залишається пропорційній вмісту $\mathrm{CO}_{2}$, може бути у різних рослин різною; другий рівень, від $1,5 \%$ до 10-20\%, коли енергія фотосинтезу продовжує зростати разом з концентрацією, але це зростання проходить все повільніше і повільніше, у порівнянні зі збільшенням концентрації $\mathrm{CO}_{2}$; третій рівень, від $20 \%$ і вище, коли фотосинтез падає у міру збільшення концентрації $\mathrm{CO}_{2}$; нарешті, четвертий рівень, приблизно 70 \% і вище, коли фотосинтез зовсім припиняється». Оптимальною для фотосинтезу автор [6] вважає концентрацію $\mathrm{CO}_{2}$ в атмосфері 5-8 \%, тобто в 139-222 рази вище, ніж в даний час. На основі тези 5 можна припустити, що вказана кількість $\mathrm{CO}_{2}$ в атмосфері (5-8 \%) буде також благотворно діяти і на дихання людини. Чи так це? Звернемося до [7]: «Спільна дія гіпоксії та гіперкапнії на фізіологічні функції вивчена не повністю, хоча саме такі газові порушення характерні для ряду як фізіологічних, так і патологічних ситуацій... Всебічний аналіз літературного матеріалу і власні дані показують, що найбільш оптимальний вплив гіпоксія та гіперкапнія справляють у співвідношенні $10 \% \mathrm{O}_{2}$ та 8-12\% $\mathrm{CO}_{2}$ у газовій суміші, що вдихається».

3 цього ж питання [8]: «... 3 моменту виникнення ціанобактерій співвідношення двох найважливіших для біологічних об'єктів газів - кисню $\left(\mathrm{O}_{2}\right)$ та вуглекислого газу $\left(\mathrm{CO}_{2}\right)$ - в атмосфері змінилося на багато порядків. Спочатку $\mathrm{O}_{2} / \mathrm{CO}_{2}$ практично дорівнювало нулю, а в сучасній атмосфері воно становить більш ніж 500! Цікаво, що всередині клітини і в міжклітинному просторі це співвідношення є близьким до одиниці».

На основі викладеного сформулюємо тезу 6.

Теза 6. Сучасним природознавством накопичено значну кількість фактів, що дозволяють з позицій ЕК зробити наступний висновок: одним 3 важливих кроків людини, здійснення якого зумовлено ходом іï еволюції, як невід'ємної частини біосфери, є зміна нею складу вдихуваного повітря. 3 зазначених позицій оптимальним для подальшого розвитку всього живого на планеті, включаючи саму людину, видається такий склад атмосфери: кисень - 10-12\%, вуглекислий газ - 8-12\%, азот 76-82\%, решта - як і в даний час.

Зазначимо, що вказаний склад повинен «вводитися» в повсякденне життя людини поступово, спочатку, наприклад, в медицині, потім - на виробництві та в побуті. І починати необхідно зі складу, підказаного природою, - зі складу видихуваного

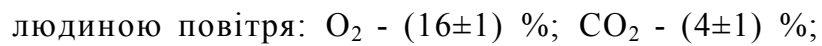
$\mathrm{N}_{2}$ - $(79 \pm 1) \%$. Передбачається, як мінімум, два заперечення проти тези 6.

заперечення 1. Людині не під силу штучно змінити газову атмосферу планети, це фантазія. Відповідь: Людина навчилася жити і працювати, наприклад, при температурах за $-30{ }^{\circ} \mathrm{C}$, і при цьому вона не «утеплювала» клімат на всій планеті, а «утеплила» лише зону, що безпосередньо прилягає до їі тіла (одягом), житлову зону (квартира) i робочу зону (виробничі приміщення, транспортні засоби тощо). Аналогічним чином вона діятиме i у випадку 3 атмосферним повітрям: спочатку забезпечить оптимальну атмосферу в зоні роботи і відпочинку, а потім вже, поступово, по всій планеті. заперечення 2. Де докази того, що про- 
понований в тезі 6 склад атмосферного повітря $\epsilon$ оптимальним для людини? Відповідь: непрямі докази є в науковій літературі, що відзначає факт збільшення функціональних резервів організму людини при спільній дії гіпоксії та гіперкапнії [7], а також факт наявного і приблизно рівного одиниці співвідношення $\mathrm{O}_{2} / \mathrm{CO}_{2}$ всередині клітини й у міжклітинному просторі [8]. Прямим доказом вірності тези 6 повинен стати медичний експеримент, в ході якого також необхідно буде підтвердити (або спростувати) твердження, сформульоване в тезі 7 .

Теза 7. Оскільки оптимальний склад атмосферного повітря, згідно з ЕК, є фактором, що визначає тривалість життя Homo sapiens, можна стверджувати, що, варіюючи між собою концентрації і тривалості спільного впливу на людський організм гіпоксійно-гіперкапнійних газових сумішей, можна вирішити одну 3 центральних проблем сучасної медицини - проблему боротьби із злоякісними пухлинами.

Теза 7 є «пробним каменем» для всієї ЕК - його можна перевірити в експерименті та клініці безпосередньо на хворих.

Розглянемо тепер злоякісну пухлину з позицій EK.

\section{4. Що таке рак із позицій енергетичної кон- цепції}

Як відомо, на підставі численних експериментальних та клінічних даних, однією з найхарактерніших рис злоякісних пухлин є знижена потреба їхніх тканин у кисні, і чим нижчою $є$ напруга кисню в тканинах пухлини, тим вона агресивніша [9]. 3 позицій ЕК цей факт трактується наступним чином.

Згідно 3 ЕК, головною біологічною функцією людини і вищих ссавців є споживання і зв'язування кисню, який являє собою упредметнену енергію, що надійшла ззовні в біосферу і на деякий час залишилася вільною (теза 4).

До тих пір, поки людський організм виконує цю функцію, кисень забезпечує енергією всі енерговитратні процеси життєдіяльності людини. У міру того, як тканини організму людини знижують споживання кисню (згідно з ЕК, цей процес починається відразу після припинення росту організму, тобто приблизно з 25 років [1]), в їі організмі починають утворюватися механізми, що ведуть до його «самознищення» [1]. Коли споживання кисню тканинами організму знижується до деякого критичного рівня (для кожного організму цей рівень може бути індивідуальним), відповідний механізм «самознищення» запускається в дію.

Зниження споживання кисню тканинами організму спричиняється спільною дією сили тяжіння, що сприяє, зокрема, закриттю капілярів, а також зниженням напруженості внутрішнього електричного поля організму (ВЕПО), індукованого в ньому власним електричним полем Землі [1]. При зниженні напруженості ВЕПО, зокрема, зменшується величина негативного електричного заряду на мембранах еритроцитів, що створює додатковий опір для їх проходження по капілярах.

Отримавши свободу від пригнічувальної дії кисню, нормальні клітини «передпухлинної» тканини потрапляють в умови, коли в них активізуються гени, що сприяють інтенсивному нарощуванню власної маси за рахунок посиленого споживання глюкози. Раніше присутність надлишкового кисню блокувала активацію цих генів. Клітина переходить 3 окисного фосфорилювання на гліколіз - споживає більше глюкози і менше кисню [10].

Отже, виникає ситуація, коли частина тканин організму (пухлинна тканина), живе і розвивається в умовах для неї істотно набагато сприятливіших, ніж інші тканини здорового організму. Результатом $\epsilon$ прискорений ріст злоякісної пухлини (оскільки перебігає в більш сприятливих для цього гіпоксійних умовах) у порівнянні з іншими тканинами організму, що знаходяться в умовах пригнічувальної дії кисню. Очевидною, з позицій ЕК, відповіддю на питання «Що робити в цій ситуації?», є теза 8.

Tеза 8. Для того, щоб дати можливість організму відновити процес нормального диференціювання пухлинних клітин і тим самим усунути їх злоякісний обмін, необхідно помістити весь організм 3 пухлинною хворобою в такі ж сприятливі для його функціонування умови, в яких знаходиться пухлинна тканина, тобто помістити організм 3 пухлиною в гіпоксійно-гіперкапнійне середовище.

Режим переходу організму, ураженого пухлинною хворобою, до оптимального функціонування, тобто початкова та кінцева концентрації гіпоксійногіперкапнійної суміші, а також швидкість зміни концентрацій їі складових до терапевтичних величин, підбираються дослідним шляхом. Починати, ймовірно, слід з найпростішого поєднання $\mathrm{O}_{2}+\mathrm{CO}_{2}$ $=16+4 \%$. Отже, з позицій ЕК, усунення пухлинної хвороби може бути досягнуто шляхом зміни факторів зовнішнього середовища, а не пригніченням росту або знищенням ракових клітин різними способами і засобами в самому організмі. 


\section{Література}

1. Щукин В. С. Что такое жизнь с точки зрения геофизики? / В. С. Щукин // Физика сознания и жизни, космология и астрофизика. - 2012. - Т. 2, № 12. - С. 51-63.

2. Идеи В. И. Вернадского в современной биологии: планетно-космические основы организации жизни / А. С. Пресман. - М. : Знание, 1976. - С. 12.

3. Цветок Гильгамеша. Природная и инструментальная оротерапия / В. А. Березовский. - Донецк : Издатель Заславский А. Ю., 2012. - С. 35.

4. Майр Э. Эволюция / Майр Э. - М. : Мир, 1981. -

C. 135 .

5. Возникновение жизни / Д. М. Бернал. - М. : Мир, 1969. - C. 73.
6. Ещё к вопросу о функциональной энергии листа в фотосинтезе: избранные труды / В. Н. Любименко. - К. : Издательство АН УССР, 1963. - Т. 1. - С. 396.

7. Гипоксия-гиперкапния и функциональные возможности организма / В. С. Сверчкова - Алма-Ата : Наука, 1988. - С. 127.

8. Мурадян Х. К. Искусственная атмосфера, омоложение и долголетие // Проблемы старения и долголетия. - 2008. - Т. 17, № 4. - С. 472.

9. Мосиенко В. С. Взгляд на современное состояние и будущее онкологии // Здоров'я України. Онкологія 2014. - № 5 .

10. Шапот В. С. Биохимические аспекты опухолевого роста / Шапот В. С. - М. : Медицина, 1975. - 304 с. 